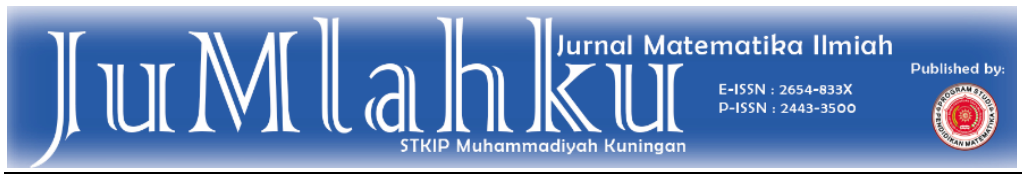

Submited: 2019-07-19

Published: 2020-06-01

\title{
Pengaruh Pendekatan Rigorous Mathematical Thinking (RMT) terhadap Kemampuan Berpikir Kreatif Siswa SMP Kelas VII
}

Siti Mahmudaha), Harina Fitriyani ${ }^{\text {b) }}$

a) (Pendidikan Matematika, Fakultas Keguruan dan IImu Pendidikan, Universitas Ahmad Dahlan) sitimahmudah1901@gmail.com

b) (Pendidikan Matematika, Fakultas Keguruan dan IImu Pendidikan, Universitas Ahmad Dahlan) harina.fitriyani@pmat.uad.ac.id

\section{Article Info \\ Kaywords : Creative \\ thinking, Geometry,} Rigorous mathematical thinking (RMT).

\begin{abstract}
One of the purposes of mathematics education is to make students think creatively. The result of creative thinking is creativity. But in fact this creativity is less concerned by teachers in learning. So the creative thinking skills need to be developed again. Stimulus is one of the ways to develop creative thinking skills. Geometry is one of the fields in mathematics. The geometry of the middle level one of them learns about the rectangular and triangular planar figure. Geometry material is material that is difficult for students to understand because it is difficult for students to grasp the concept of the material. Rigorous mathematical Thinking (RMT) is a learning approach that has three important elements that encourage students to better understand the concept of a material. With the student's reward for the concept of material, the student's creative thinking skills will be better. This research aims to determine the influence of RMT's approach to the creative thinking skills of students. The research method used was experiment method and the research design used was posttest only control design. The results of the research with a significant level of $5 \%$ showed that the creative thinking abilities of students learning with the RMT approach were better than students who studied with the scientific approach. This is indicated by the results of one part $t$ -

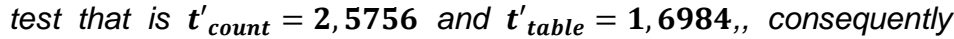
$\boldsymbol{t}_{\text {count }}^{\prime}>\boldsymbol{t}_{\text {table }}^{\prime}$, so that $\boldsymbol{H}_{\mathbf{0}}$ is rejected and $\boldsymbol{H}_{1}$ accepted. But the better criterion does not refer to the overall indicator, just one two criterion.
\end{abstract}


Kata Kunci: Berpikir kreatif, Geometri, Rigorous mathematical thinking (RMT).

\begin{abstract}
Abstrak
Salah satu tujuan pendidikan matematika adalah menjadikan siswa berpikir kreatif. Hasil dari berpikir kreatif disebut kreatifitas. Namun pada kenyataanya kreatifitas ini kurang diperhatikan oleh guru dalam pembelajaran. Sehingga kemampuan berpikir kreatif perlu dikembangkan lagi. Pemberian stimulus adalah salah satu cara untuk mengembangkan kemampuan berpikir kreatif. Geometri adalah salah satu bidang dalam matematika. Geometri pada tingkat menengah salah satunya mempelajari tentang bangun datar segiempat dan segitiga. Materi geometri merupakan materi yang sulit dipahami oleh siswa karena sulitnya siswa menangkap konsep dari materi tersebut. Rigorous mathematical Thinking (RMT) merupakan pendekatan pembelajaran yang memiliki tiga unsur penting yang mendorong siswa lebih memahami konsep suatu materi. Dengan pahamnya siswa akan konsep suatu materi maka kemampuan berpikir kreatif siswa akan lebih baik. Untuk itu penelitian ini bertujuan untuk mengetahui pengaruh pendekatan RMT terhadap kemampuan berpikir kreatif siswa. Metode penelitian yang digunakan adalah metode eksperimen dan desain penelitian yang digunakan adalah posttest only control design. Hasil penelitian dengan taraf signifikan $5 \%$ menunjukkan bahwa kemampuan berpikir kreatif siswa yang belajar dengan pendekatan RMT lebih baik dari siswa yang belajar dengan pendekatan scientific. Hal ini ditunjukkan dengan hasil uji t satu pihak yaitu $t^{\prime}{ }_{\text {hitung }}=2,5756$ dan $t_{\text {tabel }}^{\prime}=1,6984$, akibatnya $t_{\text {hitung }}^{\prime}>t_{\text {tabel }}^{\prime}$, sehingga $H_{0}$ ditolak dan $H_{1}$ diterima. Namun kriteria lebih baik tidak merujuk pada keseluruhan indikator, hanya satu dua kriteria saja.
\end{abstract}

\section{PENDAHULUAN}

Perkembangan ilmu pengetahuan dan teknologi yang begitu pesat tak bisa dipungkiri oleh siapapun. Perkembangan IPTEK yang pesat tentu tak luput dari sumber daya manusia yang handal. Sumber daya yang handal yang melebihi teknologi yang dibuatnya. Kemampuan yang handal yang dimaksud salah satunya adalah kemampuan dalam berpikir tingkat tinggi yaitu berpikir logis, kritis, kreatif dan berkerja sama secara proaktif (Ansari, 2016). Hal ini senada dengan salah satu tujuan pendidikan matematika yaitu agar siswa memiliki kemampuan berpikir kreatif (Putra \& dkk, 2012). Kemampuan berpikir 12 kreatif ini penting karena sangat diperlukan peserta didik untuk menghadapi persoalan hidup di masa yang akan datang (Afiah \& dkk, 2012). Berpikir kreatif adalah adalah kemampuan untuk menghasilkan ide atau gagasan yang baru dalam menyelesaikan masalah bahkan menghasilkan cara baru sebagai solusi alternatif (Lestari \& Yudhanegara, 2018). Dalam berpikir keratif terdapat 4 aspek yang digunakan untuk mengukur apakah seseorang mempunyai kemampuan berpikir kreatif yaitu fluency, flexibility, originality dan elaboration (Hendriana \& dkk, 2017). Keseluruhan aspek tersebut masing-masing mempunyai indikator tersendiri. 
Sesuai dengan tujuan pendidikan matematika di atas, proses pembelajaran matematika di kelas haruslah menumbuhkan kemampuan berpikir kreatif siswa. Namun pada kenyataannya pembelajaran di sekolah tidak menekankan pada penanaman kosep melainkan berfokus pada perhitungan-perhitungan saja (Hendriana \& Soemarmo, 2017). Permbelajaran di sekolah biasanya terdiri dari 3 fase yaitu: 1) diajarkan teori/definisi/teorema; 2) diberikan contohcontoh soal; 3) diberikan latihan soal (Noer, 2011). Guru masih menganggap bahwa kerativitas siswa bukanlah menjadi sesuatu yang penting dalam pembelajaran (Saefudin, 2012). Padahal kerativitas siswa perlu dikembangkan terlebih lagi dalam memecahkan masalah matematika (A. P. Sari \& dkk, 2017). Terlebih lagi kreativitas merupakan salah satu keterampilan yang harus dikuasai siswa di abad 21 ini (Pusfita \& Fitriyani, 2017). Dalam hal ini, kreativitas dipandang sebagai hasil atau produk dari berpikir kreatif (Siswono, 2004). Empat strategi yang dikemukakan UNESCO terkait pendidikan abad 21 adalah learn to know, learn to do, learn to be dan learn together (Pusfita \& Fitriyani, 2017). Dua dari empat strategi tersebut yaitu learn to know dan learn to do merupakan strategi yang berhubungan dengan kognitif siswa, dimana siswa belajar untuk mengetahui dan mencari segala pengetahuan yang diperlukan individu dan belajar tidak akan bermakna jika tidak dibarengi dengan praktek atau mengerjakan sesuatu sebagai bentuk nyata. Kemampuan berpikir kreatif dalam matematika diperlukan dalam membantu mencapai kompetensi tersebut (Santoso \& dkk, 2014). Hasil dari PISA yang dilakukan pda tahun 2003 dan TIMSS pada tahun 2011 menyatakan bahwa masih perlunya meningkatkan kemampuan berpikir kreatif dan kemampuan ini tidak akan berkembang jika tidak adanya stimulus (Abdurrozak \& dkk, 2016). Stimulus atau rangsangan ini salah satunya diperoleh dari guru. Namun faktanya, masih banyak guru yang kurang memperhatikan kemampuan berpikir kreatif siswa-siswanya (Fardah, 2012). Hal ini dapat dilihat dari seringnya guru memberikan tes menggunakan soal-soal rutin dari pada soal soal yang mengandung pemecahan masalah (Siswono \& Novitasari, 2007). Salah satu ciri soal yang memuat pemecahan masalah adalah soal tersebut berbentuk soal cerita yang dalam penyelesaiannya memerlukan gabungan dari beberapa konsep di dalam matematika. Soal dengan ciri tersebut disebut juga masalah matematika.

Pada kurikulum 2013 telah diterapkan soal dengan tipe HOTS atau high order thinking skills yaitu tipe soal yang dapat dikatakah bukan lagi soal matematika melainkan masalah matematika. Berdasarkan hasil observasi yang dilakukan, saat diberikan soal dengan tipe HOTS, siswa belum bisa menyelesaikan soal tersebut secara mandiri melainkan memerlukan bantuan guru. Hal ini akibat dari kurang aktifnya siswa selama pembelajaran. Dari yang dipaparkan sebelumnnya dapat disimpulkan bahwa ketidakaktifan siswa membuat siswa belum bisa menguasai 
konsep. Kurangnya penguasaan konsep ini mengakibatkan siswa kesulitan untuk menyelesaikan soal dengan tipe HOTS secara mendiri dan masih memerlukan bantuan dari guru. Kurangnya penguasaan konsep ini juga menjadi pengaruh bagi kemampuan berpikir kreatif siswa, karena dalam berpikir kreatif siswa memerlukan konsep untuk menyelesaikan suatu masalah matematika sehingga dapat disimpulkan bahwa kemampuan berpikir kreatif siswa masih rendah.

Dari tes yang dilakukan saat awal penelitian diperoleh hasil bahwa kemampuan berpikir kreatif siswa masih rendah. Dalam penelitian ini indikator dari aspek-aspek berpikir kreatif lebih ditekankan lagi supaya lebih terarah. Aspek fluency merujuk pada kemampuan memberikan lebih dari satu jawaban dalam menyelesaikan masalah maematika. Flexibility merujuk pada kemampuan memberikan cara penyelesaian lebih dari saru untuk menyelesaikan masalah matematika. Originality merujuk pada keunikan cara yang digunakan dalam menyelesaikan masalah matematika. Keunikan dinilai dari cara yang digunakan dalam menyelesaikan masalah matematika. Pada materi bangun datar keunikan dinilai dari bangun datar yang digunakan dalam menyelesaikan masalah matematika yang disajikan. Terakhir adalah elaboration yang merujuk pada kedetailan dan runtut tidaknya penyelesaikan masalah yang dilakukan.

Dari uraian di atas maka hendaknya guru mencoba pendekatan pembelajaran baru. Pendekatan pembelajaran merupakan strategi yang digunakan guru untuk memperjelas arah pembelajaran unutk mencapai tujuan pembelajaran yang diinginkan. Salah satu pembelajaran yang dapat dicoba adalah pendekatan rigorous mathematical thinking atau biasa disingkat RMT. RMT dari sudut pandang sebagai pendekatan pembelajaran dipandang sebagai suatu ppendekatan yang dalam prakteknya memanfaatkan fungsi kognitif untuk meningkatkan fungsi abstraksi (Fitriyani \& Khasanah, 2017). Fungsi abstraksi sendiri berkaitan dengan konsep. Menurut Gagne konsep adalah suatu ide abstrak yang memungkinkan kita untuk mengelompokkan objek ke dalam contoh dan non contoh (A. Sari \& Yuniati, 2018). Sehingga dapat diambil kesimpulan bahwa pendekatan RMT ini dapat meningkatkan pemahaman konsep siswa. hal ini dijelaskan dalam penelitian lain yang menyatakan bahwa pendekatan RMT berfokus pada memediasi siswa dalam membangun proses kognitif yang kuat bersamaan dengan membangun konsep matematika (Irawati \& Kusumawati, 2016). Pendekatan RMT adalah pendekatan yang didasarkan pada dua teori utama yang memungkinkan untuk mengkonstruksi secara aktif fungsi kognitif yaitu teori peralatan psikologis Vygotsky dan konsep belajar termediasi Feurstein (Kinard \& Kozulin, 2008). Peralatan psikologis adalah salah satu dari dua konsep penting yang terdapat pada teori sosiokultural Vygotsky. Peralatan psikologis adalah segala sesuatu 
yang mengandung makna khusus dan berguna dalam menguasai suatu fungsifungsi psikologis alami seseorang di dalam kultural dan masyarakat (Hamzah \& Muhlisrarini, 2014). Pembelajaran termediasi atau mediated learning experience (MLE) dideskripsikan sebagai sebuah kualitas istimewa dari interaksi antara seorang mediator dengan pelajar (Tzuriel, 2013). Mediator yang dimaksud ialah guru, orang tua atau pun orang dewasa lain. Mediator ini nantinya bertindak sebagai stimulus yang mengembangkan seseorang atau stimulus yang memodifikasi seseorang.

Selain dua konsep utama dalam RMT terdapat unsur lain yang digunakan dalam RMT yaitu scaffolding. Scaffolding ini adalah salah satu istilah dalam teori sosiokulturak vigotsky. Scaffolding adalah sebuah teknik untuk mengubah level dukungan di sepanjang sesi pengajaran (Santrock, 2007). Sehingga dapat disimpulkan RMT adalah suatu pendekatan pembelajaran dengan cara memediasi siswa menggunakan kriteria MLE yang dalam pembelajarannya menggunakan peralatan psikologis yang sesuai dan teknik scaffolding untuk menjembatani kognnitif siswa. Dalam pemdekatan RMT terdapat 3 fase dan 6 langkah proses yang dalam pelaksanaanya harus terpenuhi keseluruhan namun tidak harus runtut (Irawati \& Kusumawati, 2016). Dengan demikian pembelajaran RMT tidak hanya dapat mengembangkan kemampuan kognitif melainkan mengembangkan kemampuan afektif pula (Fardillah \& dkk, 2018).
Salah satu materi matematika yang dipelajari pada tingkat SMP adalah geometri. Pada tingkat VII siswa mempelajari tentang bangun datar yaitu segiempat dan segitiga. Menurut Siswono (2007) materi segiempat dapat digunakan untuk mengidentifikasi kemampuan berpikir kreatif siswa (Santoso \& dkk, 2014). Kenyataan dilapangan ketika dihadapakan dengan masalah geometri, siswa merasa takut, terbebani, tidak bersemangat dan tidak percaya diri (Khabib \& Manov, 2013). Keadaan tersbeut tentu saja dapat menjadikan pembelajaran matematika menjadi sesuatu hal yang menakutkan. Hal-hal tersebut terjadi karena lemahnya pemahaman konsep oleh siswa (Khabib \& Manov, 2013).

Dengan unsur-unsur yang terdapat pada pendekatan RMT ini diduga dapat meningkatkan penguasaan konsep matematika sehingga berpengaruh pada kemampuan berpikir kreatif siswa. Hal ini sesuai dengan tujuan penelitian ini yaitu mengetahui ada tidaknya perbedaan kemampuan berpikir kreatif siswa yang belajar dengan pendekatan RMT dan siswa yang belajar dengan pendekatan scientific dan mengetahui apakah kemampuan berpikir kreatif siswa yang belajar dengan pendekatan RMT lebih baik dari siswa yang belajar dengan pendekatan scientific.

\section{METODE}

Jenis penelitian ini adalah penelitian kuantitatif. Metode penelitian yang digunakan adalah metode eksperimen (Sugiyono, 2018). Desain penelitian yang digunakan adalah true 
experimental design. Alasan dari pemilihan desain ini karena di dalam desain ini terdapat desain yang dalam pengambilan data hanya dilakukan sekali. Dalam true experimental desain terdapat dua desain yaitu posttest only control design dan pretest only control design (Sugiyono, 2018). Penelitian ini menggunakan posttest only control design yang artinya pengambilan data dilakukan setelah perlakuan diberikan. Dalam metode eksperimen terdapat dua kelas yang digunakan yaitu kelas eksperimen dan kelas kontrol. Berikut adalah tabel yang menunjukkan desain penelitian yang digunakan

Tabel 1. Desain penelitian

\begin{tabular}{|c|c|c|}
\hline Kelompok & Perlakuan & Posttest \\
\hline Eksperimen & $\mathrm{X}$ & $\mathrm{T}$ \\
\hline Kontrol & - & $\mathrm{T}$ \\
\hline
\end{tabular}

Keterangan:

$X$ : Perlakuan berupa pembelajaran dengan pendekatan RMT

$T$ : Tes untuk mengukur kemampuan berpikir kreatif siswa

Pengambilan kelas sebagai kelas eksperimen dan kelas kontrol didasarkan pada sampel yang diperoleh. Sebelum memilih sampel terlebih dahulu ditentukan populasi. Populasi yang digunakan dalam penelitian ini adalah kelas VII SMP Muhammadiyah 3 Yogyakarta yaitu kelas VII A, VII B, VII G dan VII H. Pengambilan sampel menggunakan teknik sampling purposive (Sugiyono, 2018). Pertimbangan yang digunakan adalah hasil rata-rata hasil 16
PTS dan juga kelas yang murni sebagai kelas regular. Sehingga sampel yang diambil adalah kelas VII G dan VII $\mathrm{H}$. Sesuai denga design penelitian yang digunakan maka pengambilan data dilakukan dengan tes berupa posttest. Tes dilakukan setelah pemberian perlakuan. Tes terdiri dari 5 soal yang masing-masing berfungsi untuk mengukur kemampuan berpikir kreatif. Sebelum digunakan soal tes tersebut di uji validitas dan reliabititas. Uji validitas yang digunakan adalah validitas konstrak. Setelah uji validitas seluruh soal dinyatakan valid. Kemudian dari uji reliabilitas soal dinyatakan reliabel. Terdapat dua uji statistika yang digunakan yatu uji prasyarat analisis dan uji hipotesis. Uji prasyarat analisis meliputi uji normalitas dan uji homogenitas. Uji normalitas menggunakan uji Kolmogorov-smirnov sedangkan uji homogenitas menggunakan uji $\mathrm{F}$. Kemudian uji hipotesis menggunakan uji $t^{\prime}$. Penggunaan uji ini karena uji $t^{\prime}$ digunakan untuk mencari pengaruh suatu perlakuan.

\section{HASIL DAN PEMBAHASAN Hasil penelitian}

Sebelum memberikan perlakuan terlebih dahulu diperiksa kemampuan awal siswa. Kemampuan awal siswa diperoleh dari hasil PTS siswa. Hasil dari uji prasyarat analsis kemampuan awal diperoleh bahwa kemampuan awal kelas eksperimen dan kelas kontrol normal yang ditunjukkan pada tabel berikut: 
Tabel 2. Hasil uji normalitas kemampuan awal

\begin{tabular}{|c|c|c|}
\hline \multirow{2}{*}{ Variabel } & \multicolumn{2}{|c|}{ Perlakuan } \\
\cline { 2 - 3 } & $\begin{array}{c}\text { Kelas } \\
\text { eksperimen }\end{array}$ & $\begin{array}{c}\text { Kelas } \\
\text { kontrol }\end{array}$ \\
\hline$D_{\text {hitung }}$ & 0,086 & 0,178 \\
\hline$D_{\text {tabel }}$ & 0,236 & 0,240 \\
\hline Berdasarkan & tabel $2, \quad$ dengan taraf
\end{tabular}
signifikansi 5\% dan daerah penolakan $D_{\text {hitung }}>D_{\text {tabel }}$, maka data tersebut normal. Kemudian dialnjutkan dengan uji homogenitas. Hasil uji homogenitas dapat dilihat pada tabel berikut:

Tabel 3. Hasil uji homogenitas kemampuan awal

\begin{tabular}{|c|l|}
\hline Variabel & Nilai \\
\hline$F_{\text {hitung }}$ & 1,35 \\
\hline$F_{\text {tabel }}$ & 2,084 \\
\hline
\end{tabular}

Dengan taraf kepercayaan sama seperti sebelumnya dan daerah penolakan $F_{\text {hitung }}>F_{\text {tabel }}$, maka berdsarkan tabel 3 kedua data dinyatakan homogen. Selanjutnya dilakukan uji hipotesis. Berikut adalah hasil dari uji hipotesis yang dilakukan:

Tabel 4. Hasil uji kemampuan awal

\begin{tabular}{|c|l|}
\hline Variabel & Nilai \\
\hline$t_{\text {hitung }}$ & 0,9845 \\
\hline$t_{\text {tabel }}$ & 1,6706 \\
\hline
\end{tabular}

Sesuai dengan daerah penolakan atau kriteria uji yang diberikan yaitu $\left|t_{\text {hiutng }}\right|>$ $t_{\text {tabel }}$ maka $H_{0}$ diterima yang berarti bahwa tidak terdapat perbedaan kemampuan awal antara kelas eksperimen dan kelas kontrol. Daerah penolakan berarti jika perhitungan yang dilakukan memenuhi daerah penolakan tersebut maka $H_{0}$ ditolak.

Kemudian setelah dilakukan perlakukan lalu diberikan tes. Ringkasan hasil tes tersebut dapat dilihat pada tabel berikut:

Tabel 5. Ringkasan skor hasil posttest

\begin{tabular}{|l|l|l|l|}
\hline \multicolumn{1}{|c|}{ Kelas } & $\begin{array}{c}\text { Skor } \\
\text { terting } \\
\mathbf{g i}\end{array}$ & $\begin{array}{c}\text { Skor } \\
\text { terenda } \\
\mathbf{h}\end{array}$ & \multicolumn{1}{|c|}{$\begin{array}{c}\text { Rata- } \\
\text { rata }\end{array}$} \\
\hline Eksperimen & 24 & 3 & 10,125 \\
\hline Kontrol & 11 & 1 & 6,379 \\
\hline
\end{tabular}

Dari tabel 5 di atas dapat dilihat bahwa secara keseluruhan rata-rata skor yang diperoleh kelas eksperimen lebih tinggi daripada kelas kontrol. Setelah dilakukan penentuan skor, dilanjutkan dengan pengujian statistik. Terlebih dahulu dilakukan uji prasyarat analisis. Pertama dilakukan uji normalitas, hasil dari uji normalitas dapat dilihat pada tabel berikut:

Tabel 6. Hasil uji normalitas hasil posttest

\begin{tabular}{|c|c|c|}
\hline \multirow{2}{*}{ Variabel } & \multicolumn{2}{|c|}{ Perlakuan } \\
\cline { 2 - 3 } & $\begin{array}{c}\text { Kelas } \\
\text { eksperimen }\end{array}$ & $\begin{array}{c}\text { Kelas } \\
\text { kontrol }\end{array}$ \\
\hline$D_{\text {hitung }}$ & 0,2199 & 0,1568 \\
\hline$D_{\text {tabel }}$ & 0,2360 & 0,2460 \\
\hline
\end{tabular}

Dari tabel 6, dengan taraf kepercayaan 5\% dan daerah penolakan $D_{\text {hitung }}>D_{\text {tabel }}$, maka diperoleh hasil bahwa kedua data berdistribusi normal. Kedua, karena kedua data normal maka dilakukan uji homogenitas. Hasil uji homegenitas tertera pada tabel berikut: 
Tabel 7. Hasil uji homogenitas

\begin{tabular}{|c|l|}
\hline Variabel & \multicolumn{1}{|c|}{ Nilai } \\
\hline$F_{\text {hitung }}$ & 3,7955 \\
\hline$F_{\text {tabel }}$ & 2,076 \\
\hline
\end{tabular}

Dari tabel 7, dengan taraf kepercayaan $5 \%$ dan daerah penolakan $F_{\text {hitung }}>F_{\text {tabel }}$ diperoleh hasil bahwa data tidak homogen. Akibat dari data yang tidak homogen maka pengujian hipotesis dilakukan dengan menggunakan $u j i-t^{\prime}$. Terlebih dahulu dilakukan uji $t^{\prime}$ dua pihak. Uji ini dilakukan untuk mengetahui ada tidaknya perbedaan kemampuan berpikri kreatif siswa yang belajar dengan pendekatan RMT dan siswa yang belajar dengan pendekatan scientific. Hasil dari uji $t^{\prime}$ dua pihak dapat dilihat pada tabel berikut:

Tabel 8. Hasil uji-t dua pihak posttest

\begin{tabular}{|c|c|}
\hline Variabel & Nilai \\
\hline$t_{\text {hitung }}^{\prime}$ & 2,57559 \\
\hline$t_{\text {tabel }}^{\prime}$ & 2,04203 \\
\hline
\end{tabular}

Dengan taraf kepercayaan $5 \%$ dan daerah penolakan $\left|t^{\prime}{ }_{\text {hiutng }}\right|>t_{\text {tabel }}$, maka berdasarkan tabel 8 di atas $H_{0}$ ditolak yang berarti terdapat perbedaan kemmapuan berpikir kreatif siswa yang belajar dengan pendekatan RMT dan siswa yang belajar dnegan pendekatan scientific. Slenjutnya untuk mengetahui apakah kemampuan berpikir kreatif siswa yang belajar dengan pendekatan RMT lebih baik daripada siswa yang belajar dengan pendekatan scientific dilakukan uji-t' satu pihak. Hasil dari uji tersbeut disajikan dalam tabel berikut:
Tabe 9. Hasil uji-t satu pihak posttest

\begin{tabular}{|c|l|}
\hline Variabel & Nilai \\
\hline$t_{\text {hitung }}^{\prime}$ & 2,57559 \\
\hline$t_{\text {tabel }}^{\prime}$ & 1,69662 \\
\hline
\end{tabular}

Dengan taraf kepercayaan $5 \%$ dan daerah penolakan $t_{\text {hitung }}^{\prime}>t_{\text {tabel }}$, maka berdasarkan tabel 9 di atas diperoleh hasil bahwa $H_{0}$ ditolak. Hal ini berarti bahwa kemampuan berpikir kreatif siswa yang belajar dengan pendekatan RMT lebih baik daripada siswa yangbelajar dengan pendekatan scientific.

\section{Pembahasan}

Berdasarkan hasil penelitian yang diuraikan ditass dapat ditarik kesimpulan bahwa pendekatan RMT memberikan pengaruh terhadap berpikir kreatif siswa. pergaruh yang dimakudkan adalah pendekatan RMT memerikan dampak yang lebih baik bagi kemampuan berpikir kreatif siswa.Hal ini sesuai dengan berbagai peneltian sebelumnya. Salah satunya penelitian yang dilakukan oleh Hendrayana, A (2017) yang menghasilkan bahwa kemampuan pemahaman konsseptual matematis siswa yang belajar dengan pendekatan RMT lebih besar daripada siswa yang belajar dengan pendekatan konvensional. Sesuai dengan pembahasan sebelumnya bahwa pemahaman konsep sangat diperlukan dalam menunjang kemampuan berpikir kreatif siswa. Presentase kemampuan berpikir kreatif kelas kesperimen dan kelas kontrol disajikan dalam tabel berikut: 
Tabel 10. Presentase indikator berpikir kreatif hasil posttest

\begin{tabular}{|c|c|c|}
\hline \multirow{2}{*}{ Indikator } & \multicolumn{2}{|c|}{ Kelas } \\
\cline { 2 - 3 } & Eksperimen & Kontrol \\
\hline Fluency & $60,94 \%$ & $37,93 \%$ \\
\hline Flexibility & $17,36 \%$ & $7,66 \%$ \\
\hline Originality & $29,86 \%$ & $20,69 \%$ \\
\hline Elaboration & $24,65 \%$ & $17,24 \%$ \\
\hline Rata-rata & $33,20 \%$ & $20,88 \%$ \\
\hline
\end{tabular}
indikator fluency dimana selisih antara kelas eksperimen dan kelas kontrol adalah $23,01 \%$. Pencapaian indikator ini belum bisa dibilang sempurna karena masih jauh dari $100 \%$. Masih rendahnya indikatir ini dikarenakan siswa cenderung puas dengan satu yang diberikan. Siswa memilih menjawab satu dan benar daripada dua tapi hanya satu yang benar. Hal seperti ini masih tertanam pada siswa sehingga tujuan atau penekakan indikator ini masih belum maksimal. Presentase teredah dari kedua kelas yaitu flexibility. Indikator ini mengukur banyaknya cara yang digunakan siswa dalam menyelesaikan masalah matematika. Namun, siswa masih kebanyakan hanya memberikan satu langkah atau cara penyelesaian dari setiap soal yang diberikan yang mengukur indikator ini. Masalah yang dialami siswa yang berkaitan dengan indikator ini adalah siswa merasa kesulitan dalam menentukan bangun-bangun datar yang menyusun suatu soal. Siswa kurang bisa mengeksplor bangun pendukung yang tersirat dari suatu soal. Contoh pada gambar berikut:

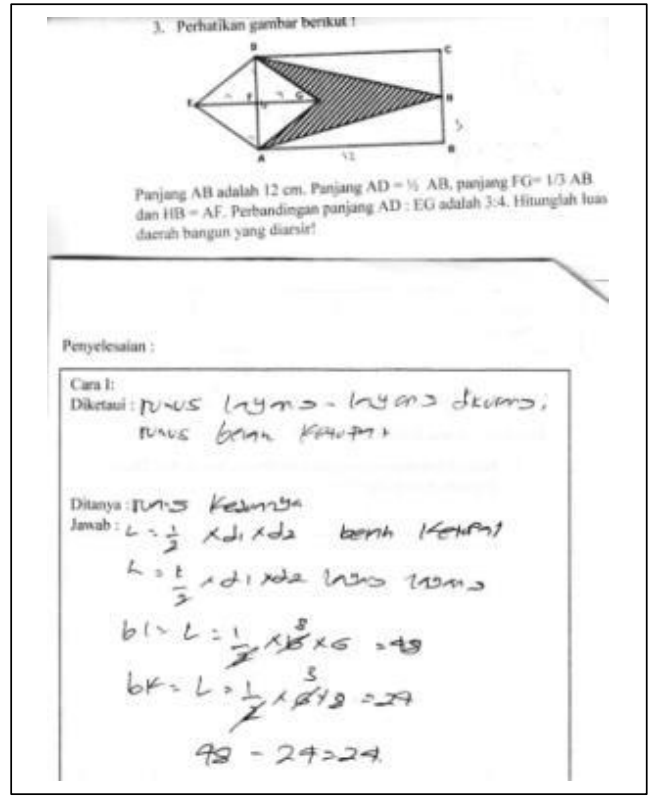

Gambar 1. Jawaban siswa soal nomor 3

Gambar 1 merupakan jawaban terbanyak siswa pada kelas eksperimen. Jawaban tersebutdiperoleh dengan mengurangkan bangaun layang-lanyang dengan belah ketupat. Namun, kebanyakan siswa juga hanya memberikan satu jawaban dengan cara tersebut. Padahal masih banyak cara lain yang dapat digunakan dalam menyelesaikan masalah di atas.Misalkan dengan mengurangkang segitiga $\mathrm{ADH}$ dengan segitiga $A D G$ atau mengurangkan persegi panjang $A B C D$ dengan tiga segitiga di dalamnya atau dapat juga dengan mengurangkan trapesium ABHD dan dua segitiga di dalamnya. 
Indikator lainnya yaitu originality yaitu indikator yang mengukur keunikan jawaban yang diberikan. Pada indikator ini, jawbaan yang diberikan siswa kebanyakan kurang unik. Kurang unik disini yang dimaksud adalah siswa masih memberikan jawaban dengan cara yang biasa saja yang semua orang pasti langsung terpikirkan cara yang sama begitu melihat soal pertama kali. Perhatikan gambar berikut:

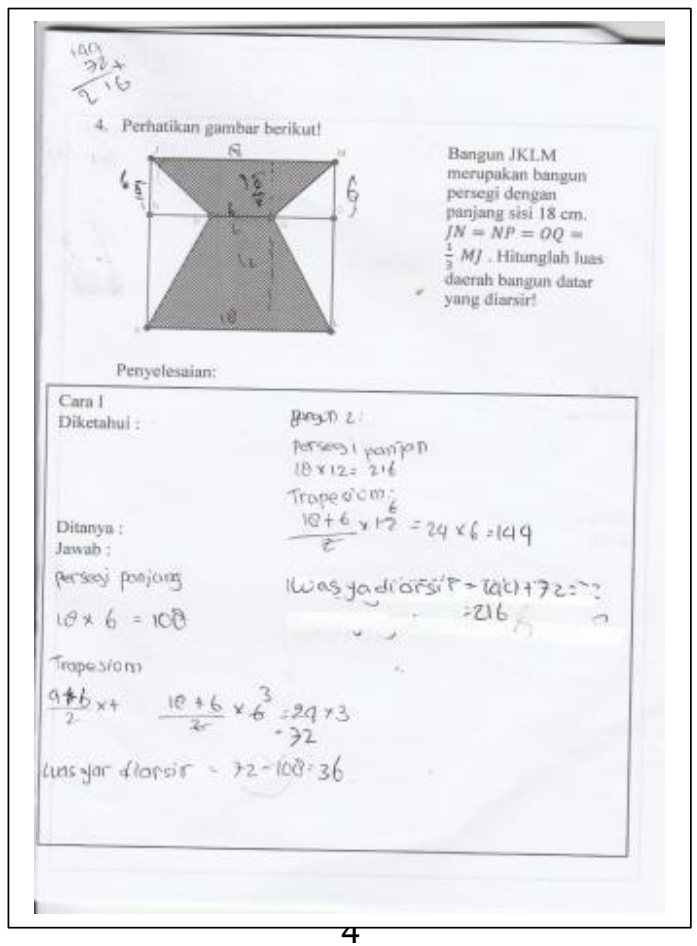

Gambar 2. Jawaban siswa soal nomor 4
Pada soal yang tertera pada gambar 2 banyak siswa yang menjawab dengan menjumlahkan dua trapesium yang diarsir. Bangun datar trapesium jelas sekali terlihat secara langsung dan merupakan penyusun utama bangun datar tersebut. Padahal petunjuk soal yang diberikan berkaitan dengan luas persegi JKLM. Sehingga untuk mencari luas daerah bangun yang diarsir memerlukan langkah yang sedikit panjang. Berbeda jika kita melihat bangun yang tidak diarsir dari persegi yang terbentuk yaitu bangun layang-layang. Kemudian kita dapat mencari luas daerah yang dicari dengan mengurangkan luas persegi yang sudah tertera pada petunjuk soal dengan layang-layang tersebut. Cara yang cukup sederhana namun banyak siswa yang belum mmenggunakannya. Siswa hanya terpaku pada bangun datar yang dilihatnya pertama kali sebagai penyusun soal sehingga menghiraukan bangun datar pelengkap yang diberikan.

Indikator terakhir adalah elaborasi. Indikator ini megukur kerincian dan keruntutan jawaban siswa. indikator ini pun masih memperoleh presentase yang rendah pula. Pada jawbaan-jawaban siswa sbenarnya sudah mencantumkan apa yang diketahui dari soal atau identifikasi soal yang diberikan yang dapat membantunya dalam menyelesaikan masalah yang diberikan, namun identifikasi yang dilakukan siswa ini kurang teliti sehingga apa yang dia gunakan di soal tiddak dimasukkan dalam identifikasi masalah. hal lain yang menjadikan skor dalam indikator ini rendah adalah terdapat beberapa siswa 
yang langsung menuliskan jawabanyya saja tanpa identifikasi masalah yang diberikan.

Dari penjelasan yang disampaikan mengenai indikator berpikir kreatif, jelas bahwa kemampuan berpikir kreatif siswa masih rendah. Hal ini sesuai dengan peneltian yang dilakukan oleh Siswono (2004) dimana taraf berpikir siswa kelas I SMP atau kelas VII masih pada taraf kurang kreatif artinya hanya memenuhi salah satu atau dua atau indikator berpikir kreatif. Hal ini juga terjadi pada penelitian yang dilakukan oleh penulis karena setiap indikator memperoleh skor atau presentase yang berbeda. Menurut penelitian yang dilakukan oleh Siswono (2004) siswa cenderung puas dengan data yang diperoleh dengan pengajuan masalah yang diberikan soal sehingga tidak ada penambahan data yang diharapkan muncul dari imajinasinya. Hal yang sama juga terjadi pada penelitian yang dilakukan oleh penulis yaitu siswa cenderung puas dengan apa yang diperoleh dari pertama kali melihat dan membaca soal tanpa mau mengamati lebih jauh lagi soal tersebut.

\section{PENUTUP \\ Simpulan}

Dari uraian diatas dapat ditarik kesimpulan bahwa pendekatan RMT dapat memberikan pengaruh pada kemampuan berpikir kreatif siswa. Pengaruh yang diberikan terhadap kemampuan berpikir kreatif siswa lebih baik daripada pendekatan pembelajaran yang biasanya digunakan oleh guru pengampu mata pelajaran. Namun kriteria lebih baik bukan mengacu pada keseluruhan indikator berpikir kreatir. Kriteria ini berlaku hanya pada jika dibandingkan dengan kelas kontrol atau kelas tanpa perlakuan.

\section{Saran}

Berdasarkan hasil penelitian yang telah dilakukan oleh penulis, maka penulis menganjurkan saran salah satunya bagi peneliti berikutnya yaitu diharapkan dapat mengembangkan dan menggunakan pendekatan pembelajaran ini dengan lebih baik lagi. Hal ini dikarenakan selama penelitian yang dilakukan penulis mengalami beberapa kendala. Salah satu saran yang dapat penulis sarankan adalah untuk mengadakan kuis dengan suatu pernghargaan misal makanan atau minuman. Hal ini dapat membuat siswa lebih termotovasi lagi dalam belajar.

\section{DAFTAR PUSTAKA}

Abdurrozak, R., \& dkk. (2016). Pengaruh Model Problem Based Learning Terhadap Kemampuan Berpikir Kreatif Siswa. Jurnal Pena IImiah Program Studi PGSD Universitas Pendidikan Indonesia, 1(1), 871880.

Afiah, I. N., \& dkk. (2012). Pengaruh Penerapan Metode Socratic Circles disertai Media Gambar terhadap Kemampuan Berpikir Kreatif Siswa. BIOEDUKASI Jurnal Pendidikan Biologi Universitas Sebelas Maret, 4(3), 1-15.

Ansari, B. I. (2016). Komunikasi Matematik, Strategi Berfikir dan Manajemen 
Belajar : Konsep dan Aplikasi. Banda Aceh: PeNa.

Fardah, D. K. (2012). Analisis Proses dan Kemampuan Berpikir Kreatif Siswa dalam Matematika Melalui Tugas Open-Ended. Jurnal Kreano Jurusan Matematika FMIPA UNNES, 3(2).

Fardillah, F., \& dkk. (2018). Kemampuan Literasi Statistis Mahasiswa Melalui Pendekatan Rigorous Mathematical Thinking (RMT). GAUSS: Jurnal Pendidikan Matematika, 1(2), 128-136.

Fitriyani, H., \& Khasanah, U. (2017). Student's Rigorous Mathematical Thinking Based On Cognitive Style. Journal of Physics: Conference Series, 943(1).

Hamzah, H. M. A., \& Muhlisrarini. (2014). Perencanaan dan Strategi Pembelajaran Matematika. Jakarta: PT Rajagrafindo Persada. Hendriana, H., \& dkk. (2017). Hard Skills dan Soft Skills Matematik Siswa. Bandung: PT Refika Aditama.

Hendriana, H., \& Soemarmo, U. (2017). Penilaian Pembelajaran Matematika. Bandung: PT Refika Aditama.

Irawati, F., \& Kusumawati, I. B. (2016). Pengembangan

Perangkat Pembelajaran Dengan Pendekatan Berfikir Matematis Rigorous (RMT) Pada Materi Bangun Ruang di Kelas VIII di SMP Nusantara Krian. Jurnal
Pendidikan Matematika STKIP PGRI Sidoarjo, 4(1), 9-16.

Khabib, Z., \& Manov, J. T. (2013). Pengembangan Perangkat Pembelajaran Dengan Pendekatan Rmt Ditinjau Dari Fungsi Kognitif Siswa Pada Materi Melukis Segitiga Di Kelas VII SMP. MATHEdunesa : Jurnal Matematika FMIPA UNESA, 2(3).

Kinard, J. T., \& Kozulin, A. (2008). Rigorous Mathematical Thinking: Conceptual Formation in the Mathemathics Classroom New York: Cambridge University Press.

Lestari, K. E., \& Yudhanegara, M. R. (2018). Penelitian Pendidikan Matematika. Bandung: Refika Aditama.

Noer, S. H. (2011). Kemampuan berpikir kreatif matematis dan pembelajaran matematika berbasis masalah open-ended. Jurnal Pendidikan Matematika, 5(1), 104-111.

Pusfita, D., \& Fitriyani, H. (2017). Penerapan Model Pembelajaran Problem Posing untuk Meningkatkan Kreativitas. PROSIDING SEMINAR NASIONAL \& INTERNASIONAL.

Putra, T. T., \& dkk. (2012). Meningkatkan Kemampuan Berpikir Kreatif Siswa dengan Pembelajaran Berbasis Masalah. Jurnal Pendidikan Matematika, Part 3, 1(1), 22-26.

Saefudin, A. A. (2012). Pengembangan Kemampuan Berpikir Kreatif Siswa 
Dalam Pembelajaran Matematika Dengan Pendekatan Pendidikan Matematika Realistik Indonesia (PMRI). Al Bidayah Jurnal Pendidikan Dasar Islam UIN Sunan Kalijaga, 4(1), 37-48.

Santoso, H. R. W., \& dkk. (2014). Deskripsi Tingkat Kemampuan Berpikir Kreatif (TKBK) Pada Materi Segiempat Siswa Kelas VII Smp Negeri 1 Pabelan Kabupaten Semarang. Jurnal Satya Widya Pendidikan Matematika Universitas Kristen Satya Wacana, 30(2), 82-95.

Santrock, J. W. (2007). Psikologi Pendidikan (T. Wibowo, Trans. 2 ed.): Prenada Media Group.

Sari, A., \& Yuniati, S. (2018). Penerapan Pendekatatan

Realistic Mathematics Educations (RME) terhadap Kemampuan Pemahaman Konsep Matematis. Jurnal Cendekia : Jurnal Pendidikan Matematika, 2(2), 7180.

Sari, A. P., \& dkk. (2017). Proses Berpikir Kreatif Siswa Dalam Memecahkan Masalah Matematika Berdasarkan Model Wallas. Beta Jurnal Tadris Matematika Universitas Syiah Kuala, 10(1), 18-32.

Siswono, T. Y. E. (2004). Identifikasi Proses Berpikir Kreatif Siswa dalam Pengajuan Masalah (Problem Posing) Matematika Berpandu dengan Model Wallas dan Creative Problem Solving (CPS). Buletin Pendidikan

$\begin{array}{lrr}\text { Matematika } & \text { Prodi } & \text { Pendidikan } \\ \text { Matematika } & \text { FKIP } & \text { UNPATTI } \\ \text { Ambon, 6(2). } & & \end{array}$

Siswono, T. Y. E., \& Novitasari, W. (2007). Meningkatkan Kemampuan Berpikir Kreatif Siswa Melalui Pemecahan Masalah Tipe "What's Another Way". Jurnal Pendidikan Matematika "Transformasi, 1(1), 113.

Sugiyono. (2018). Metode Penelitian : Kuantitatif, Kualitatif dan R\&D. Bandung: Alfabeta.

Tzuriel, D. (2013). Mediated Learning Experience and Cognitive Modifiability. Journal of Cognitif Education and Psycology, 12(1), 59-80. 